\title{
Self-Efficacy, Performance, Training and Well-Being of Industrial Workers in Lagos, Nigeria
}

\author{
E. M. Ajala ${ }^{1}$ \\ ${ }^{1}$ Department of Social Work, University of Ibadan, Ibadan, Nigeria \\ Correspondence: E. M. Ajala, Department of Social Work, University of Ibadan, Ibadan, Nigeria. Tel: \\ 234-803-565-3135. E-mail: majekajala@yahoo.com
}

\author{
Received: April 3, $2013 \quad$ Accepted: April 24, $2013 \quad$ Online Published: May 14, 2013 \\ doi:10.5539/ijps.v5n2p66 URL: http://dx.doi.org/10.5539/ijps.v5n2p66
}

\begin{abstract}
The main purpose of this study was to investigate whether Self- Efficacy (SE) has anything to do with industrial employees' training, performance and well-being in Nigeria industrial settings. Self-Efficacy (belief about one's ability to accomplish specific tasks) form a central role in the regulatory process through which an individual's motivation and performance are governed. It also affects employees' training and well-being. The descriptive survey research design of the ex-post facto type was adopted. The population for the study consisted of employees of SKG Lagos, Glaxo, Ikeja and Smithkline Beecham, Ogba. The simple random sampling technique was used to select 274 respondents for the study. Four research instruments structured on a modified four point rating format of Strongly Agree $(S A)=4$, Agree $(A)=3$, Disagree $(D)=2$. Strongly Disagree $(S D)=1$ were used and having reliability coefficient of: Self-Efficacy Scale $(\mathrm{SES})=0.85$; Training Acquisition Scale (TAS) $=0.80$; Work Performance Scale $($ WPS $)=0.82$ and Well-being Scale $(W B S)=0.87$. Data were analyzed with t-test statistic. The finding revealed that workers with high self-efficacy are higher performers of assigned duties than those with low self - efficacy, workers with high level of self-efficacy are more amenable to training than those with low level of self - efficacy and workers with high self-efficacy are better in their well-being than those with low self - efficacy. It was recommended that industrial social worker should work on the psychic of the workers so that their self-efficacy can be developed or strengthen positively with the intent of promoting higher performance, adaptability to training and fostering of employees well-being.
\end{abstract}

Keywords: self-efficacy, training, performance, well-being, industrial employees

\section{Introduction}

Self-efficacy has been popular in Industrial-Organisational (I-O) psychology. Virtually every area in organisational research has made use of self-efficacy. The area of utilisation include performance evaluation (Bartol, Durham \& Poon, 2001), stress (Jex, Bliese, Buzzell, \& Primeau, 2001), training (Kozlowski, Gully, Brown, Salas, Smith, \& Nason, 2001), career choice (Lent, Brown \& Larkin, 1987), coping with difficult career-related tasks (Stumpf, Brief \& Hartman, 1987). Given its successful application in many domains where individuals have autonomy, self-efficacy theory appears to be particularly well suited for industrial work organisations context (both profit and non-profit oriented).

Self-efficacy (SE), also called perceived ability; refers to the confidence people have in their abilities that they can successfully perform a particular task. It is also said to be a judgement of one's ability to execute a particular behaviour pattern (Bandura, 1978; 1997). Wood and Bandura (1989) expanded upon these definitions by suggesting that self-efficacy beliefs form a central role in the regulatory process through which an individual's motivation and performance are governed. Therefore, a person's self-efficacy is a strong determinant of his/her effectiveness, persistence, strategizing, as well as subsequent training and job performance (Bandura \& Locke, 2003). Besides being highly predictive, self-efficacy can also be developed in order to harness its performance enhancing benefits (Heslin \& Klehe, 2006). Self-efficacy is concerned not with the actual skills one has, but with judgements about what one can do with those skills. It arises from the gradual acquisition of complex cognitive, social, linguistic and/or physical skills through experience. Efficacious beliefs contribute to effective performance and promote well-being by encouraging goal setting and commitment, persistent effort, perseverance, resilience, reduction in stress and depression (Bandura, 2000; Bandura \& Locke, 2003).

Self-efficacy has been confirmed to promote employees performance and reduction of emotional exhaustion. For 
example, efficacious individuals seek, integrate and use information to increase role clarity and performance (Brown, Ganesan \& Challagalla, 2001), contribute to unit performance (Pillai \& Williams, 2004), have higher cognitive engagement and performance (Lent, Schmidt \& Schmidt, 2006), higher self-set goals and higher individual performance (Phillips \& Gully, 1997), more job focused and higher productivity (McDonald \& Siegall, 1992 ) and less prone to emotional exhaustion (well-being) (Grau, Salanova \& Peiro, 2001). In contrast, less efficacious individuals are more prone to burnout (Perrewe, Hochwarter, Rossi, Wallace, Maigan, Castro, Ralston, Westman, Vollmer, Tang, Wan, \& Van Deusen, 2002), psychological strain (Jex, Bliese, Buzzell \& Primeau, 2001) and engage in self-limiting behaviours (Dickerson \& Taylor, 2000) with resultant effect on lowering performance at any facet of life. These review and citations on organisational behaviour based on self-efficacy showed that an improvement on self-efficacy will improve both individual and organisational performance.

The relationship between self-efficacy and performance is a cyclical one (Kreitner \& Kinicki, 2004). Efficacy and performance cycles can spiral upward toward success or downward toward failure (Lindsley, Brass \& Thomas, 1995). There exist strong linkages between high self-efficacy expectations and success in widely varied physical and mental tasks, anxiety reduction, addiction control pain, tolerance, illness recovery, avoidance of sea-sickness in naval cadets and stress avoidance (Gecas, 1989; Stevens, Bavetta \& Gist, 1993; Eden \& Zuk, 1995; Jex, Bliese, Buzzell \& Primeau, 2001). Conversely, those with low self-efficacy expectations tend to have low success rates.

Robbins (2003) in describing self-efficacy as individual's belief that he or she is capable of performing a task, confirm that employees who believe in their abilities exhibit high levels of self-confidence and performance. During strenuous and challenging situations, employees who have high self-efficacy work very hard in order to overcome the obstacles and respond positively to negative feedback by increasing their effort and motivation (Stajkovic \& Luthans, 1998).

Since self-efficacy is a science of one's capabilities to mobilise the motivation, cognitive resources, and course of action needed to meet given situational demands (Muchinsky, 2003), therefore, there is need to develop a sense of self-efficacy in employees especially through the use of training in both public and private work organisations. Goldstein and Ford (2002) define training as the systematic acquisition of skills, rules, concepts or attitudes that result in improved performance. Trainees with low self-efficacy will not be amenable to training hence low performance. Ford, Quinones, Sego and Speer (1991) confirmed the importance of developing a sense of self-efficacy in trainees by stating that trainees need to feel confident and positive about being able to learn the material. Colquitt, Lepine and Noe (2000) confirmed the use of meta-cognitive activities as the best form for training of trainees. They emphasise the importance of motivation to learn as an aspect for successful training. Colquitt et. al. (2000) established that general cognitive ability and motivation to learn correlated significantly with learnt declarative knowledge (knowledge about facts and things). Similarly, Eden and Aviram (1993) showed the positive effect of a workshop on trainee's self-efficacy and consequent effect on job performance.

People are likely to become anxious or depressed when they perceive themselves as unable to manage aversive events or gain what they value highly. Thus, self-efficacy is related to experiencing stress and occupational burnout (Helsin \& Klehe, 2006). The implication of this statement is that low efficacy can readily lead to a sense of helplessness and hopelessness about one's capability to cope with the challenges and demand of one's job. When this occurs, distress and depression is likely to be noticed in the individual and poor performance will set in.

Low self efficacy leads to workers having burnout and distress. With low efficacy, a worker may not be able to remember information, make effective decisions and take appropriate action that might be necessary for his/her performance and productivity. It has also been established that workplace aggression is common among workers with low self-efficacy who are already experiencing stress, just as co-workers aggression is also noticed among workers with low self-efficacy (Berkowitz, 1993). Other effects of low self-efficacy among workers resulting from stress are emotional exhaustion, depersonalisation and reduced accomplishment (Lee \& Ashforth, 1996).

From above review, there arose pertinent questions as to what level of self-efficacy will affect employees' performance? To what extent can training and well-being of employees be affected by self-efficacy? Various studies conducted on self-efficacy have been on unit-variate pattern, much has not been done on multi-variate factors combination on the levels of self-efficacy. It is against this gap that this study seeks to find out the effect of differences in the levels of self- efficacy of industrial workers in Nigeria on training, performance and well-being. 


\section{Hypotheses}

Based on the review of related literature the following hypotheses were tested.

Ho1: There is no significant difference in the performance of workers with high and low self-efficacy in industrial settings.

Ho2: There is no significant difference in training adaptation of workers with high and low self-efficacy in industrial settings.

Ho3: There is no significant difference in well-being of workers with high and low self-efficacy in industrial settings.

\section{Methodology}

\subsection{Research Design}

The descriptive survey research design of the ex-post facto type was used for the study.

\subsection{Population}

The population for the study is made up of employees of SKG, Lagos; Glaxo, Ikeja and Smithkline Beecham, Ogba. These organisations are profit oriented driven, hence employees productivity are germane to the survival of both the workplace and the employees themselves.

\subsection{Sampling Procedure}

A total of 100 respondents were randomly selected from each company to make a total of 300 respondents. Of the 300 questionnaire administered, 274 were properly filled and used for data analysis.

\subsection{Instrumentation}

An instrument tagged 'Self-Efficacy, Performance, Training and Well-Being Questionnaire (SEPTWQ) with four sub-sections of: Self-Efficacy Scale (SES); Training Skill Acquisition (TSA); Work Performance Scale (WPS) and Well-Being Scale (WBS), was used for data collection. All the sub-scales used had the modified four-point rating format of Strongly Agree $(\mathrm{SA})=4$, Agree $(A)=3$, Disagree $(\mathrm{D})=2$ and Strongly Disagree (SD) $=1$. Higher score on the scale indicated high self-efficiency.

1) The SES is an adapted version of SES developed by Sherer, Maddux, Mercandante, Prentice-Dunn, Jacobs and Rogers (1982). The test retest reliability of the 15 itemized instrument administered within two weeks interval yielded 0.85 .

2) WPS measured work performance using adapted format of World Health Organisation Health and Performance Questionnaire (PHQ) of WHO (2002). The reliability got after test-retest of the 10 itemised scale was 0.82 .

3) The Well-Being Scale (WBS) of Fujishiro (2005) with 12 items was adapted for the study. The reliability coefficient got after test-retest was 0.87 .

4) The Training Skill Scale (TSA) was self constructed and it contained 10 items. The reliability coefficient got for it was 0.80 .

Data collected for the study was analysed using t-test at 0.05 level of significance.

\section{Result of Findings}

\subsection{Respondents Profile}

The average age of respondents in this study is 35.7 years, while the mean length of service in the organisations is 12 years. All the respondents have attended training since joining the organisations. All agreed to fair remunerations in terms of salaries. Therefore any decline noticed in performance was not due to poor salary. $25 \%$ of respondents are having above Masters Degree, $40 \%$ are having First Degree or its equivalent, $25 \%$ are having Secondary Schools or its equivalent and 10\% Primary Level certificates.

\subsection{Hypotheses}

\subsubsection{Hypothesis 1}

There is no difference in the performance of workers with high and low self-efficacy in industrial settings. 
Table 1. T-test analysis showing difference in performance of workers' with high and low self-efficacy

\begin{tabular}{cccccccc}
\hline Variable & Level of self-efficacy & $\mathrm{N}$ & Mean & $\mathrm{SD}$ & $\mathrm{t}$ & $\mathrm{df}$ & $\mathrm{P}$ \\
\hline Worker's & Low & 128 & 20.96 & 7.07 & 2.612 & 272 & $<0.05$ \\
performance & High & 146 & 22.96 & 6.90 & & & \\
& & & & & & \\
\hline
\end{tabular}

From Table 1 above, the null hypothesis was rejected $(\mathrm{t}=2.612 ; \mathrm{p}<0.05)$. The implication is that workers with high self-efficacy are higher performers at assigned duties than those with low self - efficacy. The significant difference can be confirmed further from the means where workers with high self-efficacy $(\bar{X}=22.96)$ indicate higher performer than those with low self-efficacy $(\bar{X}=20.96)$.

4.2.2 Hypothesis 2

There is no significant difference in training adaptation of workers with high and low self-efficacy in industrial settings

Table 2. T-test analysis showing difference in training adaptation of workers' with high and low self-efficacy

\begin{tabular}{cccccccc}
\hline Variable & Level of self-efficacy & $\mathrm{N}$ & Mean & SD & t & df & P \\
\hline Adaptation & Low & 125 & 29.78 & 7.55 & 7.56 & 272 & $<0.05$ \\
to Training & High & 149 & 38.00 & 9.34 & & & \\
\hline
\end{tabular}

From Table 2 above, the null hypothesis was rejected $(\mathrm{t}=7.56 ; \mathrm{p}<0.05)$. The implication is that workers with high self-efficacy are more amenable to training than those with low self - efficacy. The significant difference can be confirmed further from the means where workers with high self-efficacy $(\bar{X}=38.00)$ imply higher adaptation to training than those with low self-efficacy $(\bar{X}=29.78)$.

\subsubsection{Hypothesis 3}

There is no significant difference in well-being of workers with high and low self-efficacy in industrial settings.

Table 3. T-test analysis showing difference in well-being of workers' with high and low self-efficacy

\begin{tabular}{cccccccc}
\hline Variable & Level of self-efficacy & $\mathrm{N}$ & Mean & SD & t & df & P \\
\hline Worker's & Low & 127 & 21.83 & 5.62 & 2.794 & 283 & $<0.05$ \\
well-being & High & 147 & 24.48 & 6.55 & & & \\
& &
\end{tabular}

From Table 3 above, the null hypothesis was rejected $(\mathrm{t}=2.794 ; \mathrm{p}<0.05)$. The implication is that workers with high self-efficacy are better in their well-being than those with low self - efficacy. The significant difference can be confirmed further from the means where workers with high self-efficacy $(\bar{X}=24.48)$ indicate higher well-being than those with low self-efficacy $(\bar{X}=21.83)$.

\section{Discussion of Findings}

From the findings, the result of hypothesis one shows that workers with high self-efficacy are higher performer than those with low self-efficacy at assigned duties in the workplace. This is in line with the findings of Hackett (1995) that workers with low self-efficacy that are engaged in tasks in which their skills are required will quickly give up in the face of slightest difficulty thereby affecting their performance. It is also consistent with the findings of Bouffard-Bouchard, Parent, Lariv and Egrave (1991), that worker with high self-efficacy engages in more effective self-regulating strategies at each level of ability hence higher performance.

The result of hypothesis two shows that workers with high self-efficacy are more amenable to training than those with low self-efficacy. This is so because individuals with high self-efficacy can perform well in training and also have positive attitude towards training usefulness (Gutherie \& Schwoerer, 1994). Such people are also likely to view themselves as capable of obtaining the extrinsic reward that may result from successful training performance (Latham, 1998). People with strong self-efficacy beliefs exert greater efforts to master a challenge (training) while those with weak self-efficacy beliefs are likely to reduce their efforts or even quit (Bandura \& 
Schunk, 1981; Brown \& Inouyne, 1978; Schunk, 1981; Weinberg, Gould \& Jackson, 1979). Since self-efficacy is belief of "I can do" (Bandura, 2000), trainees with high self-efficacy are subjectable to training. This is so because the trainee belief that he or she can successfully learn the training programmes contents. Furthermore, trainees with high self-efficacy are usually motivated to learn because they have the belief of "I will do" factor, hence, the combination of their motivation and self-efficacy propel them to quickly assimilate their training. Since training and development activities are usually directed at meeting organisational objectives (increased productivity of workers, maximum profitability, and so on), training of high self-efficacious trainees will lead to successful human resource development and sustainance of competitive advantage that ultimately enhance organizational performance.

The result of hypothesis three confirms that employee with low-self-efficacy possesses reduced personal accomplishment, that is, having decline in one's feelings of accomplishment and success. This is in line with the finding of McShane \& Glinow (2003) that the feeling of low self-efficacy has impact on competence and performance of worker, through the development of depersonalisation and emotional exhaustion, hence, less productivity or performance. Employees with low self-efficacy develop a sense of learned helplessness as they no longer believe that their efforts make a difference. With this effect, employee with low self-efficacy became distress, job performance falls and workplace accidents are more common, whereas, the converse happens to high self-efficacious workers.

\section{Implication for Managers and Industrial Social Workers}

Different aspect of the workplace needs the interface of self-efficacy on both the managers (including industrial social workers) and the employees. Kreitner and Kinicki (2004) stated that self-efficacy requires constructive action in each of the major managerial areas of: recruitment/selection of workers, job design, training and development, goal setting, leadership and mentoring and rewards.

In the area of recruitment and promotion, organisation should administer a measure of self-efficacy during hiring and/or promotion process. Employees selected on the basis of high levels of self-efficacy will behave and perform well in the workplace (Lunenburg, 2011). Furthermore, interview questions should be designed to probe job applicants' general self-efficacy so as to determine their orientation and training needs as this have to do with either low or high self-efficacies. In the area of job design, managers should be aware that boring, tedious jobs, complex, challenging and autonomous jobs tend to enhance perceived self-efficacy (Parker, 1998). Therefore, to promote high self-efficacy, managers should know that goal difficulty should match the individual's perceived self-efficacy because as self-efficacy and performance improves, goals and quality standards are made more challenging and make organisation to achieve set goals and high productivity.

With low self-efficacy employees, managers and industrial social workers should review and applaud small successes so as to serve as stepping stone to a stronger self-image and greater achievements. Managers and industrial social workers should be aware that employees' self-efficacy expectations for key tasks can be improved through mentoring, role modelling and guided experiences, hence, careful application of the mentioned treatments.

In the same view and thought of Lunenburg (2011), industrial social worker in conjunction with the human resource manager should select employee with high level of self-efficacy for training (especially if the training budget is limited). The high level self-efficacious employees will learn more from the training and use such training to enhance their job performance. The implication is improved productivity and increase organisational efficiency.

Trainers at the workplace should not teach only knowledge and skills to trainees but also teach other learning traits that will facilitate the development of self-efficacy. This can be in form of giving explicit instructions on meta-cognitive activities that increases self-efficacy and confidence. Instructors and trainers must find appropriate ways to boost the confidence of trainees who are unsure of their learning abilities, for instance, low level self-efficacies persons can learn content of their job specifications better from one-on-one training module.

The industrial social worker should work on the psychic of the workers so that their self-efficacy can be developed or strengthen positively. Employees will become amenable to training, assist them in task-diagnotic that are commensurable to employees' level of self-efficacy and forestall relapse of the attained level. Social workers in industries should use the modelling method to strengthen the positive benefit of successes based on employees' experience. Furthermore, industrial social workers should use social persuasion and psychological information on employees so as to assist in the development of self-efficacy of employees to higher level and obtain the resultant effect of workers' well-being and increase performance at the workplace. 


\section{Conclusion}

Since self-efficacy pertains to specific tasks, both the employers and employees must see to the development of high self-efficacy among them. The many benefits of high self-efficacy make it a worthwhile attribute to cultivate. Employers and employees should cultivate high self-efficacy through the simultaneous and systematic application of enactive self-mastery, role-modelling and verbal persuasion methods for the attainment of effective and efficient performance and well-being of workers thereby resulting in the achievement of organisational goals.

\section{References}

Bandura, A. (1978). Reflections on Self-Efficacy. Advances in Behavioural Research and Therapy, 1(4), 237-269. http://dx.doi.org/10.1016/0146-6402(78)90012-7

Bandura, A. (1997). Self-efficacy: The Exercise of Control. New York.

Bandura, A. (2000). Cultivate Self-efficacy for Personal and Organisational Effectiveness. In E. A. Locke (Ed.), Hard book of Principles of Organisational Behaviour. UK: Blackwell.

Bandura, A., \& Locke, E. A. (2003). Negative Self-efficacy and Goal Effects Revisited. Journal of Applied Psychology, 88(1), 87-99. http://dx.doi.org/10.1037/0021-9010.88.1.87

Bandura, A., \& Schunk, D. H. (1981). Cultivating Competence, Self-Efficacy and Intrinsic Interest Through Proximal Self-Motivation. Journal of Personality and Social Psychology, 41(3), 586-598. http://dx.doi.org/10.1037/0022-3514.41.3.586

Bartol, K. M., Durham, C. C., \& Poon, J. M. L. (2001). Influence of Performance Evaluation Rating Segmentation on Motivation and Fairness Perceptions. Journal of Applied Psychology, 86, 1106-1119. http://dx.doi.org/10.1037/0021-9010.86.6.1106

Berkowitz, L. (1993). Aggression: Its Causes, Consequences and Control. New York: McGraw Hill.

Bouffard-Bouchard, T., Parent, S., Lariv, E., \& Egrave, S. (1991). Influence of Self-Efficacy on Self-Regulation and Performance among Junior and Senior High-School Aged Students. International Journal of Behavioural Development, 14, 153-164. http://dx.doi.org/10.1177/016502549101400203

Brown, S. P., Ganesan, S., \& Challagalla, G. (2001). Self-efficacy As a Moderator of Information Seeking $\begin{array}{lllll}\text { Effectiveness. Journal of Applied } & \text { Psychology, }\end{array}$ http://dx.doi.org/10.1037/0021-9010.86.5.1043

Brown, Jr. I., \& Inouye, D. K. (1978). Learned Helplessness through Modelling: The Role of Perceived Similarity in Competence. Journal of Personality and Social Psychology, 36(8), 900-908. http://dx.doi.org/10.1037/0022-3514.36.8.900

Chen, G., \& Bliese, P. D. (2002). The Role of Different Levels of Leadership in Predicting Self - and Collective Efficacy: Evidence for Discontinuity. Journal of Applies Psychology, 87, 549-556. http://dx.doi.org/10.1037/0021-9010.87.3.549

Colquitt, J. A., Lepine, J. A., \& Noe, R. R. (2000). Toward An Integrative Theory of Training Motivation: A meta-Analytic Path Analysis of 20 years of Research. Journal of Applied Psychology, 85, 678-707. http://dx.doi.org/10.1037/0021-9010.85.5.678

Dickerson, A., \& Taylor, M. A. (2000). Self-limiting Behaviour in Women: Self-esteem and Self-efficacy as $\begin{array}{llll}\text { Predictors. Group and Organisation } & \text { Management, 25(2), 191-210. }\end{array}$ http://dx.doi.org/10.1177/1059601100252006

Eden, D., \& Aviram, A. (1993). Self-efficacy Training to Speed Reemployment: Helping People to Help Themselves. Journal of Applied Psychology, 78, 352-360. http://dx.doi.org/10.1037/0021-9010.78.3.352

Eden, D., \& Zuk, V. (1995). Seasickness as a Self-fulfilling prophecy: Raising self-efficacy to Boost Performance at Sea. Journal of Applied Psychology, October, 628-635. http://dx.doi.org/10.1037/0021-9010.80.5.628

Ford, J. K., Quinones, M., Sego, D., \& Speer, J. (1991). Factors Affecting the Opportunity to use Trained Skills on the Job. Paper presented at the $6^{\text {th }}$ Annual Conference of the Society for Industrial and Organisational Psychology, St. Louise.

Fujishiro, K. (2005). Fairness at Work: Its Impacts on Employee Wellbeing. A Dissertation of P.hd. Degree presented to the Graduate school of the Ohio State Univversity. 
Gecas, V. (1989). The Social Psychology of Self-Efficacy. In W. R. Scott, \& J. Blake. (Eds.), Annual Review of Sociology (vol. 15, pp. 291-316). Palo Alto, CA: Annual Reviews, Inc.

Goldstein, I. L., \& Ford, J. K. (2002). Training in Organisations (4th ed.). Belmont, CA: Wadsworth.

Grau, R., Salanova, M., \& Peiro, J. M. (2001). Moderator Effects of Self-efficacy on Occupational Stress. Psychology in Spain, 5(1), 63-74.

Gutherie, J. P., \& Schwoever, C. E. (1994). Individual and Contextual Influences on Self-Assessed Training Needs. Journal of Organisational Behaviour, 15, 505-422.

Hackett, G. (1995). Self-Efficacy in Career Choice and Development. In A. Bandura (Ed.), Self-Efficacy in Changing Societies. (pp. 232-258). New York: Cambridge University Press. http://dx.doi.org/10.1017/CBO9780511527692.010

Heslin P. A., \& Klehe, U. C. (2006). Self-Efficacy. In S. G. Rogelberg (Ed.), Encyclopedia of Industrial/Organizational Psychology (Vol. 2, pp. 705-708). Thousand Oaks: Sage.

Jamal, M. (1984). Job Stress and Job Performance Controversy: An Empirical Assessment. Organisational Behaviour and Human Performance, 33, 1-21. http://dx.doi.org/10.1016/0030-5073(84)90009-6

Jex, S. M., Bliese, P. D., Buzzell, S., \& Primeau, J. (2001). The Impact of Self-Efficacy on Stressor-strain Relations: Coping Style as an Explanatory Mechanism. Journal of Applied Psychology, 86(3), 401-409. http://dx.doi.org/10.1037/0021-9010.86.3.401

Judge, T. A., Jackson, C. L., Shaw, J. C., Scott, B. A., \& Rich, B. L. (2007). Self-Efficacy and Work-Related Performance: The Integrated Role of Individual Differences. Journal of Applied Psychology, 92(1), 107-127. http://dx.doi.org/10.1037/0021-9010.92.1.107

Keinan, G. (1987). Decision Making under Stress: Scanning of Alternatives under Controllable and Uncontrollable Threats. Journal of Personality and Social Psychology, 52, 635-644. http://dx.doi.org/10.1037/0022-3514.52.3.639

Kozlowski, S. W. J., Gully, S. M., Brown, K. G., Salas, E., Smith, E. M., \& Nason, E. R. (2001). Effect of Training Goals and Goal Orientation Traits in Multidimensional Training Outcomes and Performance Adaptability. Organizational Behavior and Human Decision Processes, 85, 1-31. http://dx.doi.org/10.1006/obhd.2000.2930

Kreitner, R., \& Kinicki, A. (2004). Organisational Behaviour (6th ed.). New York: McGraw-Hill, Irwin.

Latham, G. P. (1988). Human Resource Training and Development. Annual Review of Psychology, 39, 445-482. http://dx.doi.org/10.1146/annurev.ps.39.020188.002553

Lee, R. T., \& Ashforth, B. E. (1996). A Meta-Analytic Examination of the Correlates of the Three Dimensions A Job Burnout. Journal of Applied Psychology, 81, 123-133. http://dx.doi.org/10.1037/0021-9010.81.2.123

Lent, R. W., Brown, S. D., \& Larkin, K. C. (1987). Comparison of Three Theoretically Derived Variables in Predicting Career and Academic Behaviour: Self-Efficacy, Interest Congruence and Consequence Thinking. Journal of Counselling Psychology, 34(3), 293-298. http://dx.doi.org/10.1037/0022-0167.34.3.293

Lent, R. W., Schmidt, J., \& Schmidt, L. (2006). Collective Efficacy Beliefs in Student Work Teams: Relation to Self-Efficacy, Cohesion and Performance. Journal of Vocational Behaviour, 68, 73-84. http://dx.doi.org/10.1016/j.jvb.2005.04.001

Lindsley, D. H., Brass, D. A., \& Thomas, J. B. (1995). Efficacy-performance Spirals: A Multilevel Perspective. Academy of Management Review, July, 645-678.

Lunenburg, F. C. (2011). Self-Efficacy in the Workplace: Implication for Motivation and Performance. International Journal of Management, 14, 1.

McDonald, T., \& Siegall, M. (1993). The Effects of Technological Self-Efficacy and Job Focus on Job Performance, Attitudes, and Withdrawal Behaviours. Journal of Psychology, 5, 465-475.

McShane, S. L., \& Glinow, M. A. V. (2003). Organisational Behaviour: Emerging Realities for the Workplace Revolution. New York: McGraw-Hill Companies Inc.

Motowidlo, S. J., Packard, J. S., \& Manning, M. R. (1986). Occupational Stress: Its Causes and Consequences $\begin{array}{lllll}\text { for Job Performance. Journal of Applied Psychology, 71, 618-629. } & \text {. }\end{array}$ http://dx.doi.org/10.1037/0021-9010.71.4.618 
Muchinsky, P. M. (2003). Psychology Applied to Work (7th ed.). U.K: Thomson Wadsworth.

Parker, S. K. (1998). Enhancing Role Breadth Self-Efficacy: The Role of Job Enrichment and other Organisational Intervention. Journal of Applied Psychology, December, 835-852. http://dx.doi.org/10.1037/0021-9010.83.6.835

Perrewe, P. L., Hochwarter, W. A., Rossi, A. M., Wallace, A., Maigan, I., Castro, S. L., Ralston, D. A., Westman, M., Vollmer, G., Tang, M., Wan, P., \& Van Deusen, C. A. (2002). Are Work Stress Relationships Universal? A Nine Region Examination of Role Stressors, General Self-efficacy and Burnout. Journal of International Management, 8, 163-188. http://dx.doi.org/10.1016/S1075-4253(02)00052-2

Phillips, J. M., \& Gully, S. M. (1997). Role of Goal Orientation, Ability, Need for Achievement, and Locus of Control in the Self-efficacy and Goal setting process. Journal of Applied Psychology, 82(5), 792-802. http://dx.doi.org/10.1037/0021-9010.82.5.792

Pillai, R., \& Williams, E. A. (2004). Transformational Leadership, Self-efficacy, Group Cohesiveness, Commitment and Performance. Journal of Organizational Change Management, 17(2), 144-159. http://dx.doi.org/10.1108/09534810410530584

Robbins, S. P. (2003). Organizational Behaviour (10th ed.). Upper Saddle River, New Jersey: Prentice Hall Inc.

Schunk, D. H. (1981). Modelling and Attributional Effects on Children's Achievement: A Self-Efficacy Analysis. Journal of Educational Psychology, 73(1), 93-105. http://dx.doi.org/10.1037/0022-0663.73.1.93

Sherer M., Maddux, J. E., Mercandante, B., Prentice-Dunn, S., Jacobs, B., \& Rogers, R. W. (1982). The Self-Efficacy Scale: Construction and Validation. Psychological Report, 51, 663-671. http://dx.doi.org/10.2466/pr0.1982.51.2.663

Stajkovic, A., \& Luthans, F. (1998). Self-Efficacy and Work-Related Performance: A meta-Analysis. Psychological Bulletin, 124(2), 240-261. http://dx.doi.org/10.1037/0033-2909.124.2.240

Stevens, C. K., Bavetta, A. G., \& Gist, M. E. (1993). Gender Differences in the Acquisition of Salary Negotiation skills: The Role of Goals, Self-Efficacy and Perceived Control. Journal of Applied Psychology, October, 723-735. http://dx.doi.org/10.1037/0021-9010.78.5.723

Stumpf, S. A., Brief, A. P., \& Hartman, K. (1987). Self-Efficacy Expectations and Coping with Career-related Events. Journal of Vocational Behaviour, 31(2), 91-108. http://dx.doi.org/10.1016/0001-8791(87)90037-6

Weinberg, R. S., Gould, D., \& Jackson, A. (1979). Expectations and Performance: An Empirical Test of Bandura Self-Efficacy Theory. Journal of Sport Psychology, 1(4), 320-331.

WHO. (2002). The World Health Organisation Health and Work Performance Questionnaire (HPQ). Journal of Occupational and Environmental Medicine, 45(2), 156-173.

Wood, R., \& Bandura, A. (1989). Social Cognitive Theory of Organisational Management. Academy of Management Review, 14(3), 361-384. 